\title{
Effects of iron and manganese on the growth of rice and on the contents of these elements in rice plants
}

\author{
S. M. ALAM \\ Atomic Energy Agricultural Research Centre, Tandojam, Pakistan
}

SUMMARY

\begin{abstract}
A glasshouse experiment was conducted to study the influence of Fe and Mn applications in lowland alluvial soil on the growth of paddy rice and the concentration of $\mathrm{Fe}$ and $\mathrm{Mn}$ in leaves and stems. The application of $\mathrm{Mn}$ alone up to $10 \mathrm{ppm}$ increased the dry matter yield of rice, whereas yield decreased with further increase in Mn levels. Similarly addition of Fe alone up to $30 \mathrm{ppm}$ increased the dry weights but decrease was observed beyond that level. The application of $\mathrm{Mn}$ up to $10 \mathrm{ppm}$ in the presence of Fe however, increased yields at all $\mathrm{Fe}$ levels. The maximum dry matter yield was recorded when $10 \mathrm{ppm} \mathrm{Mn}$ was supplied with $30 \mathrm{ppm} \mathrm{Fe}$ Manganese concentration in leaves and stems increased with increase in Mn levels but in the absence of Fe. Its concentration also increased with Fe level up to $30 \mathrm{ppm}$. With further addition of $\mathrm{Fe}$, the $\mathrm{Mn}$ content decreased in both plant parts.

The increased application of Fe increased the Fe content of leaves and stems with and without Mn application The application of $10 \mathrm{ppm} \mathrm{Mn}$ generally increased Fe concentration in both plant parts, but higher Mn levels decreased the Fe content in plant parts.

Low levels of $\mathrm{Fe}$ and $\mathrm{Mn}$ were essential for better plant growth and efficient utilization of these nutrients by rice plants. Antagonistic effects were observed only when one of the nutrients was applied in higher quantities in the growth medium.
\end{abstract}

Additional key word : Rice nutrition

L'influence d'apports de fer et de manganèse à des sols alluviaux sur la croissance du riz et sur la concentration en ces éléments dans les feuilles et les tiges est étudiée en serre.

Le rendement en matière sèche augmente par l'apport de $\mathrm{Mn}$ seul jusqu'à 10 ppm ; au-delà, il décroît. Il en es de même pour le fer seul jusqu'à $30 \mathrm{ppm}$. Cependant, l'apport de $\mathrm{Mn}$ jusqu'à $10 \mathrm{ppm}$ augmente le rendement quelle que soit la dose de $\mathrm{Fe}$ appliquée. Le rendement maximum en matière sèche est atteint pour $10 \mathrm{ppm} \mathrm{Mn}$ et $30 \mathrm{ppm}$ Fe.

La concentration en Mn dans les feuilles et les tiges augmente, en l'absence de Fe, avec le niveau de l'apport, ainsi qu'en présence de Fe jusqu'à un apport de $30 \mathrm{ppm}$ pour cet élément ; au-delà, la teneur en Mn décroît. $\mathrm{La}$ concentration en Fe dans les feuilles et les tiges augmente lorsque l'apport de Fe augmente, avec ou sans apport de $\mathrm{Mn}$; elle augmente généralement après apport de $\mathrm{Mn}$ jusqu'à $10 \mathrm{ppm}$ mais décroît au-delà

De faibles apports de $\mathrm{Fe}$ et de $\mathrm{Mn}$ sont donc essentiels pour une meilleure croissance du riz et pour une utilisation plus efficace de ces éléments. Les effets inverses s'observent seulement lorsque l'un d'eux est apporté en trop fortes quantités.

Mot-clé additionnel : Nutrition riz

\section{INTRODUCTION}

Research work on iron and manganese in soils and plants has been conducted for many years. Many conflicting results have been reported due to different soil types and plant species investigated. Many research workers (DEKOCK, 1955 ; TISDALE \& NELSON, 1975) have reported that the absolute level of iron and manganese in the rooting medium may not be the most important factor in relation to plant growth. The re- lationship of the amount of one element to another may be more important than its absolute level.

Iron and manganese are essential micronutrients for the growth and development of plants (DEKOCK, 1955 ; Vlamis \& Williams, 1964 ; Price, 1968 ; TERRY, 1980 ; BENNET et al., 1982 ; DATIN \& WESTERMAN, 1982). Both of these nutrients are required for chlorophyll synthesis (GAVALAS \& CLARK, 1971 ; OHKI, 1975) and for the activities and function of numerous enzymes in the plant root systems (EVANS 
\& SORGER, 1966 ; DEL RIO et al., 1978). Interaction in the absorption and utilization of $\mathrm{Fe}$ and $\mathrm{Mn}$ by plants (SCHMID \& GERLOFF, 1961 ; LINGLE et al., 1963 ; Rickels \& LiNGLE, 1966 ; TIFFIN, 1972) has later been interpreted as a result of an antagonism between both these micronutrients which may be operative inside the plant when $\mathrm{Fe}$ and $\mathrm{Mn}$ compete for certain positions in enzyme systems (EvANS \& SORGER, 1966 ; PrICE, 1968).

Several workers have reported that the combined role of $\mathrm{Fe}$ and $\mathrm{Mn}$ in plant nutrition is much more important than their individual roles (KARIM \& $\mathrm{MOH}-$ SIN, 1964). Response to both $\mathrm{Fe}$ and $\mathrm{Mn}$ in the growth and nutrition of the rice plant has been reported (CHIU, 1967 ; PATEL et al., 1977 ; Alam, 1982). Some researchers (RICKELS \& LINGLE, 1966 ; DAHIYA \& SINGH, 1976 ; ALAM, 1981) have reported that $\mathrm{FeSO}_{4}$, $7 \mathrm{H}_{2} \mathrm{O}$ decreases $\mathrm{Mn}$ availability in soils. LINGLE et al. (1963) reported that $\mathrm{Mn}$ interfered with Fe uptake and transport when $\mathrm{Fe}$ and $\mathrm{Mn}$ were at equimolar concentrations. OLSEN \& WATANABE (1979) stated that Mn reduced the physiological effectiveness of $\mathrm{Fe}$ in plants, whereas others have found increased $\mathrm{Mn}$ concentrations and uptake with increasing iron levels in the growth medium (BEAUCHAMP \& RossI, 1972). At lower Mn concentrations, Mn stimulated Fe absorption. Soil $\mathrm{pH}$ also affects the solubility of micronutrients and with the exception of Mo increased soil $\mathrm{pH}$ decreases solubility. These studies have indicated the possibility of interaction between $\mathrm{Fe}$ and $\mathrm{Mn}$ in plants and as such more information is needed on this subject. Therefore, keeping the above view, the present work was undertaken to see the effects of Fe and $\mathrm{Mn}$ on the growth of and content of these elements in rice plants.

\section{MATERIALS AND METHODS}

A glasshouse experiment was set up using plastic pots of $20 \mathrm{~cm}$ surface diameter filled with $4 \mathrm{~kg}$ of alluvial soil of $\mathrm{pH} 7.6$, organic matter $0.75 \%$, total $\mathrm{N} 0.05 \%$, total P $0.04 \%$ total K $0.50 \%$, available P (Truog's) $2.51 \mathrm{ppm}$, available $\mathrm{Fe} 1.5 \mathrm{ppm}$ and citric acid soluble K $5.93 \mathrm{ppm}$. Standard methods of soil analysis were followed for determination of the above soil properties. The treatments were comprised of five levels of $\mathrm{Fe} 0,10,30,60$ and $90 \mathrm{ppm}$ as $\mathrm{FeSO}_{4}$, $7 \mathrm{H}_{2} \mathrm{O}$ and five levels of $\mathrm{Mn} \mathrm{0,5,10,20} \mathrm{and} 40 \mathrm{ppm}$ as $\mathrm{MnSO}_{4}, 4 \mathrm{H}_{2} \mathrm{O}$. Each pot received a basal application of $\mathrm{N}, \mathrm{P}$ and $\mathrm{K}$ at the rate of 80,60 and $30 \mathrm{ppm}$ respectively through reagent grade $\left(\mathrm{NH}_{4}\right)_{2} \mathrm{SO}_{4}$, $\mathrm{KH}_{2} \mathrm{PO}_{4}$ and $\mathrm{KCl}$. Four plants per pot of rice variety 'IR-8' were grown in the glasshouse under proper care. The pots were randomized and the treatments replicated three times. The conditions in the glasshouse were: day temperature $30^{\circ} \mathrm{C}$; humidity $55 \%$; night temperature $20^{\circ} \mathrm{C}$; humidity $85 \%$; the photoperiod was $16 \mathrm{~h}$. The plants were harvested after 7 weeks of growth, washed several times in distilled water, separated into leaves and stems and then dried in an oven at $70{ }^{\circ} \mathrm{C}$ for $48 \mathrm{~h}$. The dry weight of plants was recorded and the samples were then chopped into small pieces with a stainless steel scissors and mixed uniformly for further analysis. One gram portions of dried plant material were digested in a nitric, per- chloric and sulphuric acid mixture. Iron and manganese in the digest were determined using phenanthroline and periodate methods respectively (JACKSON, 1958).

\section{RESULTS AND DISCUSSION}

The application of $\mathrm{Mn}$ alone up to $10 \mathrm{ppm}$ increased the dry matter yield of rice plants, whereas it decreased with further increase of $\mathrm{Mn}$ application (table 1). The dry matter yield with $40 \mathrm{ppm} \mathrm{Mn} \mathrm{was}$ even less than that of the control $(0 \mathrm{Mn}, 0 \mathrm{Fe})$. On the other hand, the dry matter yield increased with $\mathrm{Fe}$ alone upto $30 \mathrm{ppm}$, but it decreased considerably with $90 \mathrm{ppm} \mathrm{Fe}$, though it was more than that of the control. Similarly the application of $\mathrm{Mn}$ up to $10 \mathrm{ppm}$ along with $\mathrm{Fe}$ increased the dry weight of rice plants at all levels of iron. Maximum dry matter yield was recorded when $10 \mathrm{ppm} \mathrm{Mn}$ was applied together with $30 \mathrm{ppm} \mathrm{Fe}$. The application of more than $10 \mathrm{ppm} \mathrm{Mn}$ in the growth medium decreased the dry matter yield at Fe levels beyond $30 \mathrm{ppm}$. The above results indicated that a proper balance between $\mathrm{Fe}$ and $\mathrm{Mn}$ is necessary for maximization of dry matter production.

\section{TABLE}

Effect of variable levels of $\mathrm{Fe}$ and $\mathrm{Mn}$ on the dry weight of rice $(g / p o t)$.

Effet d'apports variables de Fe et $\mathrm{Mn}$ sur le poids sec du riz ( $g / p o t)$.

\begin{tabular}{|c|c|c|c|c|c|c|}
\hline \multirow{2}{*}{$\begin{array}{c}\text { Mn levels } \\
\text { (ppm) }\end{array}$} & \multicolumn{5}{|c|}{ Fe levels (ppm) } & \multirow{2}{*}{ Mean } \\
\hline & 0 & 10 & 30 & 600 & 90 & \\
\hline 0 & 1.97 & 2.41 & 2.76 & 2.42 & 2.12 & 2.33 \\
\hline 5 & 2.10 & 2.73 & 3.54 & 2.96 & 2.56 & 2.76 \\
\hline 10 & 2.86 & 3.93 & 4.29 & 3.19 & 2.84 & 3.42 \\
\hline 20 & 2.62 & 3.15 & 3.29 & 2.92 & 2.60 & 2.92 \\
\hline 40 & 1.74 & 2.62 & 2.85 & 2.23 & 2.09 & 2.30 \\
\hline Mean & 2.26 & 2.97 & 3.34 & 2.73 & 2.44 & \\
\hline
\end{tabular}

LSD (0.05); Fe \& Mn 0.11; Fe $\times$ Mn 0.24.

Both these nutrients responded well when they were applied individually or together at low levels in the growth medium. The lower yield response observed at the higher levels indicates that a synergistic effect between $\mathrm{Fe}$ and $\mathrm{Mn}$ exists.

Manganese concentration in the leaves and stems increased up to $10 \mathrm{ppm} \mathrm{Mn} \mathrm{level} \mathrm{in} \mathrm{the} \mathrm{absence} \mathrm{of} \mathrm{Fe}$ (table 2). The proportionate increase was more in the leaves than in the stems. The application of $30 \mathrm{ppm}$ $\mathrm{Fe}$ generally increased $\mathrm{Mn}$ concentration both in leaves and stems while addition of $\mathrm{Fe}$ above $30 \mathrm{ppm}$ decreased $\mathrm{Mn}$ concentration in plant parts but their contents at higher levels were more than that of the control. The results thus indicated reduced uptake of $\mathrm{Mn}$ by rice plants in the presence of higher Fe levels. The decrease in $\mathrm{Mn}$ concentration in plant parts was attributed to a possible antagonistic reaction between $\mathrm{Fe}$ and $\mathrm{Mn}$ in the plant root system (TWYMAN, 1951 ; KANNAN \& JOSEPH, 1975 ; WAllaCE \& Muller, 1980). However, the results also indicated that low levels of $\mathrm{Fe}$ were essential for absorption and utilization of $\mathrm{Mn}$ by rice plants. These findings are in 
TABLE 2

Effect of variable levels of $\mathrm{Fe}$ and $\mathrm{Mn}$ on the Mn concentration in leaves and stems of rice. Effet d'apports variables de Fe et $\mathrm{Mn}$ sur la concentration en Mn des feuilles et des tiges de riz.

\begin{tabular}{|c|c|c|c|c|c|c|}
\hline \multirow{2}{*}{$\begin{array}{c}\text { Mn levels } \\
\text { (ppm) }\end{array}$} & \multicolumn{5}{|c|}{ Fe levels (ppm) } & \multirow{2}{*}{ Mean } \\
\hline & 0 & 10 & 30 & 60 & 90 & \\
\hline \multicolumn{7}{|c|}{ Mn concentration in leaves ( $\mathrm{ppm}$ ) } \\
\hline 0 & 60 & 117 & 139 & 134 & 122 & 114 \\
\hline 5 & 83 & 124 & 160 & 129 & 127 & 124 \\
\hline 10 & 117 & 153 & 192 & 156 & 134 & 150 \\
\hline 20 & 88 & 105 & 133 & 130 & 110 & 113 \\
\hline 40 & 84 & 68 & 112 & 87 & 70 & 84 \\
\hline Mean & 86 & 113 & 147 & 127 & 112 & \\
\hline
\end{tabular}

$\operatorname{LSD}(0.05) ; \mathrm{Fe} \& \mathrm{Mn} 4.40 ; \mathrm{Fe} \times \mathrm{Mn} 9.85$

Mn concentration in stems (ppm)

\begin{tabular}{crrrrrr}
0 & 49 & 69 & 85 & 78 & 75 & 71 \\
5 & 65 & 108 & 135 & 124 & 116 & 109 \\
10 & 91 & 133 & 138 & 122 & 117 & 120 \\
20 & 83 & 81 & 87 & 86 & 72 & 82 \\
40 & 67 & 68 & 61 & 71 & 59 & 65 \\
Mean & 71 & 92 & 101 & 96 & 88 & \\
\hline
\end{tabular}

LSD (0.05) ; Fe \& Mn $3.61 ; \mathrm{Fe} \times \mathrm{Mn} 8.06$.

agreement with the results of BEAUCHAMP \& ROSSI (1972), who reported that increasing Fe supply does not reduce $\mathrm{Mn}$ availability or concentration in barley plants when $\mathrm{Mn}$ supply ranges from below to optimum but may do so when the Mn supply is above the optimum level.

Iron concentration in plant leaves and stems increased up to $30 \mathrm{ppm}$ of Fe level, in the absence of $\mathrm{Mn}$ (table 3) and beyond this level, Fe concentration in plant parts decreased. Iron concentration also increased with $\mathrm{Mn}$ application up to $10 \mathrm{ppm}$. However, the concentration decreased with a further increase in $\mathrm{Mn}$ levels up to $40 \mathrm{ppm}$ regardless of $\mathrm{Fe}$ levels. The reason for this decrease in $\mathrm{Fe}$ concentration at higher $\mathrm{Mn}$ levels could be the interaction between $\mathrm{Fe}$ and $\mathrm{Mn}$ in the plant root system. The findings of some workers have revealed that $\mathrm{Mn}$ interfered with the ransport of $\mathrm{Fe}$ from roots to shoots (KANNAN \& JOSEPH, 1975 ; AlVAREZ-TINAUT et al., 1977). Such zffects may be operative inside the plant when Fe and
TABLE 3

Effect of variable levels of Fe and Mn on the Fe concentration in leaves and stems of rice.

Effet d'apports variables de Fe et $\mathrm{Mn}$ sur la concentration en Fe des feuilles et des tiges de riz.

\begin{tabular}{ccccccc}
\hline $\begin{array}{c}\text { Mn levels } \\
\text { (ppm) }\end{array}$ & 0 & 10 & 30 & 60 & 90 & \\
\cline { 1 - 2 } & Mean & \\
\hline
\end{tabular}

Fe concentration in leaves (ppm)

\begin{tabular}{crrrrrr}
0 & 61 & 75 & 108 & 101 & 94 & 88 \\
5 & 132 & 153 & 168 & 141 & 143 & 147 \\
10 & 215 & 333 & 383 & 272 & 167 & 274 \\
20 & 201 & 214 & 265 & 206 & 150 & 207 \\
40 & 192 & 167 & 187 & 140 & 123 & 162 \\
Mean & 160 & 188 & 222 & 172 & 135 & \\
\hline
\end{tabular}

LSD (0.05); Fe \& Mn $5.37 ; \mathrm{Fe} \times \mathrm{Mn} 12.00$

Fe concentration in stems (ppm)

\begin{tabular}{crrrrrr}
0 & 44 & 70 & 83 & 71 & 83 & 69 \\
5 & 94 & 140 & 154 & 129 & 105 & 126 \\
10 & 140 & 186 & 212 & 183 & 123 & 168 \\
20 & 118 & 135 & 149 & 131 & 109 & 129 \\
40 & 108 & 106 & 125 & 113 & 108 & 111 \\
Mean & 102 & 128 & 144 & 125 & 104 & \\
\hline \hline
\end{tabular}

LSD (0.05) ; Fe \& Mn $4.32 ; \mathrm{Fe} \times \mathrm{Mn} 9.66$.

Mn compete for certain positions in the enzyme systems (LABANAUSKAS, 1979 ; AGARWALA et al., 1982). The interaction of these nutrients inside the plant and or at the absorption sites could be physiological in nature as low Mn levels were apparently necessary for efficient utilization of Fe by rice plant and vice versa.

From the above results it was concluded that maximum dry matter yield was obtained at lower levels of Fe and Mn than at the higher levels. This may be due to the fact that at the higher levels these nutrients interact in the plant root system, inhibiting their utilization by the rice plant and resulting in the reduced dry matter yield. Higher application of $\mathrm{Fe}$ reduced the uptake of $\mathrm{Mn}$ by plant parts and vice versa. The low levels of $\mathrm{Fe}$ and $\mathrm{Mn}$ were essential for better plant growth and efficient utilization of these nutrients by rice plant.

Reçu le 29 août 1984. Accepté le 21 janvier 1985.

\section{REFERENCES}

Agarwala S. C., Mehrotra S. D., Bisht S. S., Sharma C. P., 1982. Mineral nutrient element composition of three varieties of chick pea grown at normal and deficient levels of supply. J. Ind. Bot. Soc., 58, 153-162.

Alam S. M., 1981. Effects of iron and manganese on the growth and nutrient contents of rice plants grown under flooded and unflooded conditions. Pak. J. Sci. Ind. Res., 24, 192-194.

Alam S. M., 1982. Effect of different levels of iron, manganese and phosphorus on the yield and nutrient content of rice. Pak. J. Sci. Ind. Res., 25, 118-123.

Alvarez-Tinaut M. C., Leal A., Martines L. R., 1980. Iron manganese interaction and its relation to boron levels in tomato plants. Plant and Soil, 55, 377-388.

Beauchamp E. G., Rossi N., 1972. Effect of Mn and Fe supply on the growth of barley in nutrient solution. Can. J. Plant Sci., 52, 575-581.
Bennet J. H., Edward H. L., Krizek D. T., Olsen R. A., Brown J., 1982. Photochemical reductions of iron. 11. Plant related factors. J. Plant Nutr., 5, 335-344.

Chiu T. F., 1967. Iron and manganese absorption by rice plants. Soils Fertil. Taiwan, 1, 1-6.

Dahiya S. S., Singh M., 1976. Effect of salinity, alkalinity and iron application on the availability of $\mathrm{Fe}, \mathrm{Mn}, \mathrm{P}$ and $\mathrm{Na}$ in pea (Pisum sativum L.) crop. Plant and Soil, 44, 679-702.

Datin C. L., Westerman R. L., 1982. Effect of phosphorus and iron on grain sorghum. J. Plant Nutr., 5, 703-714.

Dekock P. C., 1955. Iron nutrition of plants at high pH. Soil Sci., 79, 167-176.

Del Rio L. A., Gomez M., Yanez J., Leal A., Lopez G. J., 1978. Iron deficiency in pea plants. Effect of catalase, a peroxidase, chlorophyll and proteins of leaves. Plant and Soil, 49, 343-353. 
Evans H. J., Sorger G. J., 1966. Role of mineral elements with emphasis on the univalent cations. Annu. Rev. Plant Physiol., 17, 47-76.

Gavalas N. A., Clark H. E., 1971. On the role of manganese in photosynthesis. Plant Physiol., 47, 139-143.

Jackson M. L., 1958. Soil Chemical Analysis. Prentice Hall Inc. Englewood. Cliffs, N.J., 134 p.

Kannan S., Joseph B., 1975. Absorption and transport of $\mathrm{Fe}$ and $\mathrm{Mn}$ in germinating sorghum. Plant Physiol., 55, 1006-1008.

Karim A. Q. M. B., Mohsin M., 1964. Relationship between Fe-Mn in rice nutrition. Pak. J. Soil Sci., 1, 49-58.

Labanauskas C. K., Handy M. F., 1970. Effects of iron and manganese deficiencies on accumulation of non protein and protein amino acids in macadamia leaves. J. Am. Soc. Hortic. Sci., 95, 218-223.

Lingle J. C., Tiffin L. O., Brown J. C., 1963. Iron uptake-transport of soybeans as influenced by other cations. Plant Physiol., 38, 7176 .

Ohki K., 1975. Manganese supply, growth and micronutrient concentration in grain sorghum. Agron. J., 67, 30-32.

Olsen S. R., Watanabe F. S., 1979. Interaction of added gypsum in alkaline soils with uptake of iron, molybdenum, manganese and zinc by sorghum. Soil Sci. Soc. Am. Proc., 43, 125-130.

Patel G. J., Ramokrishanaya B. V., Patel B. K., 1977. Effect of soil and foliar application of ferrous sulphate and acidification of soil on iron chlorosis of paddy seedlings in Goradu soil in India. Plant and soil, 46, 209-219.

Price C. A., 1968. Iron compounds and plant nutrition. Annu. Rev. Plant Physiol., 19, 239-248.

Rickels J. W., Lingle J. C., 1966. Iron uptake and translocation by tomato plants as influenced by root temperature and manganese nutrition. Plant Physiol., 41, 1095-1098.

Schmid W. E., Gerloff G. C., 1961. A naturally occurring chelate of iron in xylem exudation. Plant Physiol., 36, 226-231.

Terry N., 1980. Limiting factors in photosynthesis. 1. Use of iron stress to control photochemical capacity in vivo. Plant Physiol., 65 , 114-120.

Tiffin L. O., 1972. Translocation of micronutrients in plants. In J. J. Mortvdt, P. M. Giordano and W. L. Lindsay (eds) : " Micronutrients in Agriculture"'. Soil Sci. Soc. Amer., Madison, Wis, 199229.

Tisdale S. L., Nelson W. L., 1975. Soil fertility and fertilizers. MacMillan publ. Co. Inc., New York, 95 p.

Twyman E. S., 1951. The iron and manganese requirements of plants. New Phytol., 50, 210-226.

Vlamis J., Williams D. E., 1964. Iron and manganese relations in rice and barley. Plant and Soil, 20, 221-230.

Wallace A., Muller R. T., 1980. Effect of iron level on trace metal stress in bush bean plants grown in solution culture. J. Plant Nutr., 2, 991-102. 